\title{
Analysis of Customary Institutions Position and Roles in Business Permission Bureaucracy: Case of Bali
}

\author{
${ }^{1}$ BUDDI WIBOWO, 2 BAGUS ADHI LUTHFI, ${ }^{3}$ ANAS LUTFI \\ ${ }^{123}$ Program Pascasarjana IImu Manajemen Fakultas Ekonomi dan Bisnis Universitas Indonesia \\ email: ${ }^{1}$ buddi.wibowo@ui.ac.id
}

\begin{abstract}
Uneven investment activities distribution in Bali result in economic disparity which causes not only social tension but also endanger cultural heritage. Preservation of Balinese culture could be threatened if economic and business activities are not managed properly and in line with efforts to preserve the culture of Bali in the long term. This study aims to assess the empirical and normative sociological legal jurisdiction over existing regulations related to economic and business activities in the Province of Bali which can be considered a potential threat to the preservation of Balinese culture and tradition. Based on the problem mapping that is the result of the empirical and normative juridical study, we are able to do the analysis of regulatory and institutional rearrangement of business and investment permission bureaucracy in the Bali province by considering the preservation of cultural and traditional law enforcement in Bali.
\end{abstract}

Keywords: investment, indigenous villages, preservation of culture

\section{Introduction}

In encouraging economic growth, the province of Bali relies on private investment (RKPD Bali, 2016; Trisna and Ida, 2014). Investment in Bali grew by $2.36 \%$ (yoy) and has a positive effect on unemployment level and increase the working population as much as 152.5 thousand workers (Bank Indonesia, 2015). Higher economic growth and employment has a significant impact on poverty number and welfare. The percentage of poor people in the province of Bali tend to decline during the period 2006-2013 (BPS Bali, 2014).

The role of private investment in Bali is expected to increase. FDI and domestic investment grew by an average of $16.77 \%$ (RUPM Bali 2014-2025). Data shows the realization of investment increased sharply by $689 \%$ in the month of september 2015 position of Rp. 22.9 trillion, compared to 2014 Rp. 2.9 trillion (BPMP, 2015). In the previous period, Bali had experienced a decrease in the investment climate based on research of International Finance Corporation (IFC). According to IFC this is due to the interference of the banjar or dusun (Bali traditional village institution) which determine the completeness of the requirements for local business permission. This becomes a problem when there is a difference between the interests of employers with traditional institutions in conducting business activities. The above facts should be carefully examined since the preservation of Balinese cultural identity based on the concept of Tri Hita Karana which is supported by the existence of customary or traditional village (Santosa, 2003). One case which is an example of investment interests vis a vis the preservation of cultural identity is a case of Bali Benoa Bay reclamation (Suantika, 2015).

\section{Research Objectives}

The objectives of this research are to study all the empirical juridical relevant regulations and legislation as well as reviewing socio legal aspect so we can carry out an analysis of the investment and business permission bureaucracy restructuration in the Bali province. The result of the study are: (1) The identification of regulation discrepancies

Received: May 8, 2016, Revision: November 15, 2016, Accepted: December 19, 2016

Print ISSN: 0215-8175; Online ISSN: 2303-2499. Copyright@2016. Published by Pusat Penerbitan Universitas (P2U) LPPM Unisba Accredited by DIKTI. SK Kemendikbud, No.040/P/2014, valid 18-02-2014 until 18-02-2019 
and loopholes that exist so that investment and business activities in Bali could potentially threaten the preservation of Bali culture, tradition and customary law; (2) Model institutional business and investment and the role of traditional institutions; (3) measure readiness of investment permission service agencies in supporting of investment activity in the region.

\section{Research Design}

This research applied a descriptive empirical juridical and socio-legal analysis Empirical juridical analysis is conducted by reviewing all relevant legislation and local regulations (Marzuki, 2002). The empirical juridical analysis is a type of research that is oriented to the collection of facts or empirical data field concerning reviewed positive regulation. We also study the community's perceptions and behavior on existing law and assess the effectiveness of the normative law in forcing targeted behavior in the community. Perceptions were explored through interviews and focus group discussion with all stakeholders.

In evaluating the institutional business and investment permit bureaucracy, this study used empirical analysis approach to the three aspects of the legal system: the legal substance, legal structure and legal culture (Friedman, 1975). To evaluate further investment permit services institutions, modified good design fittest were used (Gold and Campbell, 2002).

\section{Conceptual Framework: Institutional Setting}

Bromley (1989) states that we need an institution that organizes and facilitates the commodity markets. This is because humans have a bounded rationality, limited information, lack of mental readiness to face huge uncertainty when they have to make a transaction. Institutions can be interpreted as an order and pattern of mutual relations binding between community members or organizations that further define the relations between people or organizations in a context of an organization or a network which is limited or tied to the specific norms, codes of conduct that control social behavior and also as incentives for work together toward a common goal (Djogo, et.al., 2003). The government requires well-functioning institutions and low transaction costs. Transaction costs generated by the institution will determine how resource are utilized, what policies are chosen, as well as what kind of technology is adopted which determine the cost of transactions (North, 1990).

\section{Bali Provincial Investment Institu- tional Model}

The government, based on Presidential Decree No. 29 of 2004 on the Implementation of the Domestic Investment (DCI) and Foreign Direct Investment (FDI) to form the Investment Coordinating Board as the organizer of investment activities that have authority related to the approval, permission, licensing investment proposal. In order to encourage economic growth, the government spur business activities that support regional development through the participation of local and foreign investors as stated in Law No. 25 of 2007 on the Capital Investment approval process which assessment of its implementation is done by the Investment Coordinating Board Centre (BKPM Pusat). The growth of investment in Bali encouraged local governments to establish Investment Board and the Regional Office (BKPM Daerah) to give service and supervision to the local level. This policy was based on:

(1) Bali provincial Regulation number 4 of 2011 on the local authority organization and function. (2) Bali Governor Regulation number 82 of 2011 concerning the details of the main tasks of investment and licensing bodies in Bali province. (3) Bali Governor Regulation number 62 of 2013 regarding the authority delegation of permission and non-permission issue the head of the investment and licensing province of Bali Article 25 paragraph (5) of Investment Law (UU Penanaman Modal) expressly states all services is integrated into one gate. Permission process should be simplified as investors do not have to go to various agencies to get investment permission, as set out in Article 26 paragraph (1) One Stop Services aims to assist investors in obtaining comprehensive service, fiscal facilities and information regarding capital investment.

Further elaboration of the one stop service stipulated in Presidential Regulation of the Republic of Indonesia Number 27 Year 2009 on One Stop Services in the Investment Permission (Presidential Decree No. 27 of 2009 concerning PTSP). Article 1 point 4 explained: One Stop Services, hereinafter referred PTSP is the activities of the holding of a permission and Non permission which 
received the authority delegation or the has authority and the institution or agency that has the authority to license and non-license management process which start from the proposal stage up to stage the publication of documents should be done in one place.

In order to achieve the investment target, the provincial government of Bali forms the Integrated Licensing Services Office (KPPT) Bali province on July 28, 2008 by issuing Bali Provincial Regulation No. 2 of 2008 refers to (i) PP 41/2007 on Guidelines for Organization of the Region; (ii) Ministry of Domestic Affair Regulation No. 57/2007 on Technical Guidelines for Planning Organization of the regional; and (iii) Permendagri $20 / 2007$. With the publication of Regulation Governor of Bali No. 36 of 2009 concerning Delegation of authority in issuing investment permission and non-permission affair to the Head of the Integrated Permission Services of Bali Province and Governor Regulation Bali Number 37 Year 2009 on Issuance of Permission and Non-Permission Procedure in Integrated Permission Services Office of Provincial Bali (KPPT), since November 19, 2009 KPPT Bali Province started its operation.

\section{Indigenous Peoples and Develop- ment in Bali}

The Republic of Indonesia is a country made up of diverse ethnic groups with distinctive traditions, cultures, and customary laws. With this national philosophy of statehood, the laws and all regulations issued by the state and are valid throughout the territory of Indonesia should consider traditional customary laws and cultures that exist in each region.

Recognition and respect for community unit customary law has been regulated in Article 18B paragraph (2) of the 1945 Constitution, states:

\begin{abstract}
"The State recognizes and respects communities customary law and their traditional rights as long as it is alive and in accordance with society advancement and the principles of the Republic of Indonesia, which is regulated by law", The provisions of Article 28 paragraph (3) of the 1945 Constitution states unequivocally: "The cultural identity and the rights of traditional communities have to be respected in line with the times evolution and advancement of civilizations."
\end{abstract}

Recognition and respect for customary law community unit as referred to Article $18 \mathrm{~B}$ paragraph (2) and Article 28 paragraph (3) has been recognized also by the founding fathers at the time of the formulation of 1945 (before amendment). Founding founders acknowledgement of the customary law was crystallized in Article 18 UUD 1945 which states that:

\begin{abstract}
"The area division of Indonesia, large and small, with the structure of its government, established by law, with consideration and through given consultative basis within state bureaucracy system, and the rights of its origins in the special areas."
\end{abstract}

Furthermore, in the Explanation II of Article 18, it is stated that "in the Indonesia country areas, there are approximately 250 zelfbesturendelandschappen, and volksgemeenschappen such as Desa in Java and Bali, Nagari in Minangkabau, Dusun and Marga in Palembang, etc. Those areas have the original order, and can, therefore, be considered as special areas." Further explanation of the article states, "The Republic of Indonesia respect the position of those special areas and all state regulations regarding the area will be given the right to acknowledge the origins of the area."

Rights of origins in the community with the original arrangement referred to above explanation are similar to the traditional right as referred to in Article 18B paragraph (2) of the 1945 Constitution.

Bali has Desa Adat (customary village) or Pakraman they have rights and obligations in regulating social life in its area. In contrast to another village such as in Java, Bali customary village has a legal basis which refers to the Bali provincial law No. 06 of 1986 about Indigenous Village. Darmadi (2011) argues traditional village is an autonomous traditional institution, has a distinct cultural community, traditions, customary law community unit, and the collective identity of the people of Bali. Bali Provincial Government accommodates the interests of those through the issuance of Regional Regulation No. 3 of 2001 which was amended in Regional Regulation No. 3 of 2003 on Pakraman. Pakrama village is a customary law community that has the unity of traditions and manners in social life which are bonded in Kahyanga Three, has a certain region, has its own property, self-regulated body, and is entitled to manage his own affair (Harmini and Solihin, 2013). From that conception of the traditional village (Pakraman), it has autonomous authority in the sense of 
having to regulate itself in accordance with the policy, initiative, and its own capability (Gorda, 1999).

\section{Juridical Analysis and Socio-Legal Business Activities and Investments in Bali}

\section{Specific Decentralization Needs}

Economic disparities between cities and counties in the province of Bali is quite severe, which is evident from the GDP per capita gap. Economic disparities are influenced by the concentration of investments. The tourism sector in Bali province is concentrated in the city of Denpasar, Badung and Gianyar so the effect on per capita income in the three regions are more prominent than another region in Bali

In 2014, the economy of Denpasar was able to grow $6.77 \%$ while the economic growth in Klungkung only reached $5.82 \%$. The phenomenon confirmed existence economy disparity in the province of Bali, where, in spite of Bali Province is still potential for growth, such growth has not enjoyed equally by all regions in Bali. From legal jurisdiction alleged economic disparity is due to the limited authority (autonomy) government of Bali in managing investment activities. The legal basis for the establishment of the province of Bali namely Law No. 64 Year 1958 on the Establishment of areas of Bali, West Nusa Tenggara and East Nusa Tenggara is still using the Provisional Constitution of 1950 which is contrary to the spirit of decentralization and regional autonomy contained in Article 18 (A) and Article 18 (B) of the 1945 Constitution and the Local Government Law No. 23 of 2014.
There are obstacles for Bali provincial government in capturing the economic growth potential areas where legally still fused with other regions. Besides, with the formation of an umbrella law provinces, according to DPD province of Bali Ngurah Arya Wedakarna, make one island system management become so difficult to implement that synergy between investors and government bureaucracy and synergy between regions are not optimal and the unequal distribution of development become more apparent.

Table 2

Economic Growth Regency/ City in Bali Province

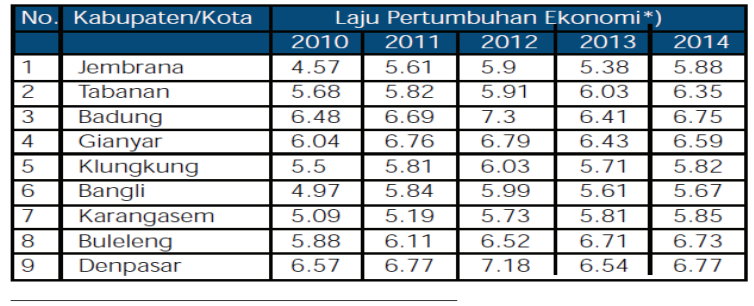

Tahun dasar 2000

Rata-rata pertumbuhan triwulan I tahun 2011 s/d 2015

Source: Bank Indonesia, 2015

\section{Economic Justice}

Bali has the competitive advantage in tourism sector because of its unique customs and culture imbued with Hinduism which is based on the philosophy of Tri Hita Karana. Until now, many Balinese people feel they have not received a fair share of the income generated from the tourism activities. Though Bali requires significant funding for maintenance, renovation, conservation, preservation facilities, infrastructure, systems, but we should always remember Bali customs

Table 1

Regional GDP per Capita in Bali Regions

Perkembangan Nilai PDRB Perkapita ADHB dengan Migas Kabupaten/Kota di Provinsi Bali Tahun 2007-2012 (000/jiwa)

\begin{tabular}{lrrrrrr}
\multicolumn{1}{c}{ Kab /Kota } & \multicolumn{1}{c}{$\mathbf{2 0 0 7}$} & $\mathbf{2 0 0 8}$ & $\mathbf{2 0 0 9}$ & $\mathbf{2 0 1 0}$ & $\mathbf{2 0 1 1}$ & $\mathbf{2 0 1 2}$ \\
\hline Jembrana & 9.768 & $\mathbf{1 1 . 2 8 3}$ & 12.649 & 13.722 & $\mathbf{1 4 . 7 4 0}$ & $\mathbf{1 6 . 3 7 7}$ \\
Tabanan & 8.475 & 9.784 & 10.838 & 11.965 & 12.874 & 14.119 \\
Badung & 18.428 & 20.988 & 24.673 & 27.296 & 29.578 & 32.850 \\
Gianyar & 10.653 & 12.268 & 13.878 & 1.552 & 16.932 & 18.706 \\
Klungkung & 11.036 & 12.766 & 14.423 & 16.056 & 17.365 & 19.121 \\
Bangli & 7.664 & 8.714 & 9.926 & 10.922 & 11.737 & 12.962 \\
Karang Asem & 7.051 & 8.167 & 9.319 & 10.394 & 11.454 & 12.766 \\
Buleleng & 8.275 & 9.552 & 10.799 & 12.063 & 13.011 & 14.218 \\
Kota Denpasar & 11.264 & 12.832 & 14.123 & 15.753 & 17.215 & 18.635 \\
BALI & $\mathbf{1 2 . 0 1 8}$ & $\mathbf{1 3 . 8 5 0}$ & $\mathbf{1 5 . 7 7 4}$ & $\mathbf{1 7 . 1 9 1}$ & $\mathbf{1 8 . 6 4 1}$ & $\mathbf{2 0 . 7 4 3}$ \\
\hline
\end{tabular}


and cultural values is a world heritage. Article 11 of Law 33 of 2004 on Financial Balance between the Central Government and the regional states that the profit sharing between the central government and local government in the tax sector and natural resources should be fair. According to Wayan Adnyana, senior Bali citizen, the source of funding can be obtained from natural resources and other resources. However, Law No. 332004 has not been accommodated yet. Other resources that may be in form of VOA (Visa On Arrival), airport tax, and levies donations. Furthermore, according to Wayan Adnyana levies, donation culture is very important in supporting cultural activities. Thus it is necessary to revise Law No. 33 of 2004, especially related article revenue sharing funds.

\section{Equality Regional Investment}

Bali has relatively stable economic growth but still has the economic disparity between districts/cities. Economic inequality is influenced by investment and business activities that have not been evenly distributed (concentrated in South Bali). For example, the realization of the investment coming from the domestic investor (DCI), from the period 2013 to 2014 were highly concentrated in South Bali, while other areas were left behind (see Table 3).

Table 3

Realization of Domestic Investment (Rp) Regency/ City in the province of Bali

\begin{tabular}{|c|c|c|}
\hline \multirow{2}{*}{ Lokasi } & \multicolumn{2}{|c|}{ Realisasi Investasi (PMDN-dalam rupiah) } \\
\hline & 2013 & 2014 \\
\hline Badung & $2,904,031,590,989.00$ & $1,658,994,907,315.00$ \\
\hline Bangli & $21,251,598,513.00$ & $23,127,666,006.00$ \\
\hline Buleleng & $201,726,516,733.00$ & $259,707,461,501.00$ \\
\hline Gianyar & $1,134,498,036,526.00$ & $430,416,872,930.00$ \\
\hline Jembrana & $80,226,771,592.00$ & $215,645,964,562.00$ \\
\hline Karang Asem & $163,428,824,530.00$ & $78,405,972,960.00$ \\
\hline Klungkung & $23,954,159,164.00$ & $65,372,018,724.00$ \\
\hline Tabanan & $108,928,442,039.00$ & $68,539,768,973.00$ \\
\hline Denpasar & $2,932,780,625,101.00$ & $1,016,227,615,767.00$ \\
\hline
\end{tabular}

Source : BPMP Bali, 2015

It is very necessary for the equitable distribution of investment in Bali. Bali provincial government may issue a regulation which gives incentives and ease of investment by referring to: (1) Act No. 25 of 2007 on Investment; (2) institutional coordination should be able to be measured by the speed of granting licenses and investment facilities at competitive costs; (3) Article 278 of Law Number 23 Year 2014 on Regional Government; (4) of Government Regulation
No. 45 Year 2008 on Guidelines for Providing Incentives and Ease of Investment in the Region

\section{Certainty and Legal Protection}

Based on the findings of this research, the main constraints faced by institutional effort and investment in Bali is legal certainty associated with the practice of a double nominee and a certificate of land ownership. It needs to give special attention on this issue, due to the absence of legal certainty which is clearly related to land and property agreements nominee, are predicted there will be 5.000 property units that are in legal dispute in Bali (K3NI, 2015).

Article 33 paragraph (1) states: "Domestic investor and foreign investor who make an investment in the form of limited liability companies (PT) are prohibited from making agreements and/or a statement confirming that the ownership of shares in a limited liability company for and on behalf of others." In the Capital Market Law expressly prohibits domestic investors and foreign investors to make an agreement and/or a statement confirming that the ownership of shares in PT for and on behalf of others. Then, in the Capital Market Law Article 33 paragraph (2) also states: "In terms of domestic investors and foreign investors to make an agreement and/or the declaration referred to in paragraph (1), the agreement and/or the statement is against law". Nominee agreement is against law. Unfortunately, the Law No. 40 of 2007 does not regulate the requirements for becoming a shareholder which can be used as a legal base to regulate or to prohibit the use of nominee shares and agreement nominee shares, so that the prohibition of agreements nominee shares in Law No. 25 Year 2007 is not efficient because nominee shares is contained narrow scope that is only in the field of common stock investment. As a result, there are a lot of activities against law in the form of a nominee agreement in Bali as they are used in order to undercover direct investment by foreign investor

Regarding dual certificate problem, Law No. 5 of 1960 on the Basic Regulation of Agrarian Principles set out in Article 4 (1), states: On the basis of the controlling right of the state as defined in Article 2 are determined the existence of a variety of rights to the earth's surface is called the land, which can be provided to and belongs to the people, either alone or together with other persons and legal 
entities. The above regulation implies that the land rights is derived from the states' rights of control over land can be granted to individuals both Indonesian citizens and foreign nationals, a group of people together, and legal entities both private legal entity or a public legal entity. But empirically, lands in Bali, especially in Badung, Denpasar, Gianyar there are multiple certificates on the same ground object. This condition indicates a lack of legal certainty and there is no guarantee of legal protection for the owner of the land ownership certificate (Suwitra, 2013).

Disharmony of policies is also an obstacle for the institutional business and investment permit in Bali. For example, the regulation of licensing revenue. In Act No. 23 of 2014 on Regional Government, there is the transitional licensing authority of the district to the province but in Law Number 28 Year 2009 on Regional Taxes and Levies are clearly mentioned that revenues from licensing are still in the district/city. It needs special attention in order to avoid investor confusion when they want to propose investment activities in a region.

Another disharmony of policy is related to national policy framework regarding set up and supervise the establishment of the onestop service (OSS). This is the consequence of the different conditions in a variety of rules that is now the basis of the existence of PTSP the Government Regulation No. 27 of 2009 (as mandated by Act No. 25 of 2007 on Investment) as a reference BKPM, and Permendagri 24 of 2006 as the reference Kemendagri which contain quite different substances, especially in terms of institutional setting. So in this case, the establishment of the one-stop service in one region was not followed by the setting of the same procedure at the level of central government.

\section{Preservation of Nature and Culture}

Bali Governor Regulation No. 63 Year 2014 about the General Investment Plan states vision and mission of investment Bali until 2025 is: "The realization of investment improvement which is sustainable with quality permission service supports towards Advanced, Safe, Peaceful and Prosperous Bali based on Tri Hita Karana," The preservation of nature and culture are associated with the concept of Tri Hita Karana where one important factor should be considered in the implementation of investment activities is the environmental factor. In Article 15 paragraph (2) letter a of Law Number 32 of 2009 on the Protection and Management of the Environment states that the regional government shall carry out the Strategic Environmental Assessment (SEA) in the preparation and evaluation of RTRWP (Land Planning and Regional Planning)

Bali RTRWP policies have a high urgency because natural environment is limited and not renewable and should be utilized in a sustainable manner based on Balinese culture imbued with Hindu religion in accordance with the philosophy of Tri Hita Karana. The existence of Regulation 16 of 2009 on RTRWP Bali give a guidance on Bali regional area planning must be closely correlated to nature and culture preservation (Windari, 2013). One of the cases is related Bali RTRWP that are filed for judicial review of Regulation No. 16 Year 2009 on Spatial Planning Bali Province 2009-2029 was submitted by I Made Deg, located at BR. Karang Office Bomo, Desa Pecatu, South Kuta, Badung regency. The request filed on June 22, 2010 and received by the clerk of the Supreme Court dated June 23, 2010, and registered with No. 30p / HUM 2010. Petitioner filed a petition for judicial review of the existing regulation because some articles considered being contrary to higher legislation. But the Supreme Court decided that the Bali Provincial Regulation 16 of 2009 does not conflict with a higher level of legislation. Based on Supreme Court decision, RTRWP Bali has a legal binding position as a basic rule of investing activities in Bali (Novianto, 2012).

Nonetheless, RTRWP is still not able to stem the eroded orientation and preservation of indigenous culture. Development of tourism accommodation continues to grow, which has a significant impact on land use both for productive and unproductive purposes (Dewantara, 2015). Development of tourism accommodation is initially only using unproductive land, but recently they start to use productive land also, for the example is Condotel, Vilatel in Coastal Lepang Klungkung. The transformation of this land made local agriculture and plantation commodities eroded. This phenomenon, if left unchecked, can damage the preservation of nature Bali, particularly can make a disruption of traditional land irrigation systems (Subak) (Suwitra, 2013).

Regulation on the environment in Bali is still limited only based on Governor Regulation No. 8 of 2007 on Environmental 
Quality Standards. Specific provincial and local regulations governing the protection of the environment is a must. Several cases had arisen such as the problem of hotel and restaurant wastewater management that contaminated 13 beaches in Bali which created a polemic between counties and cities in Bali that requires serious treatment (Erviantono, 2012). The local government of Bali needs to draft legislation related to the environment reservation referring to Law No. 32 of 2014 on the Protection and Environmental Management which need to be adjusted with the aim of developing tourism in Bali.

Bali cultural tourism also brought a negative impact in the form of community orientation changes that tends to the commercialize the culture. Previously sacred dance has already begun to perform to tourism purposes (Prayogi, 2011). Based on these facts, the Bali Provincial Regulation No. 2 of 2012 deemed not to have more detailed rules in order to maintain the cultural distinctiveness of Bali. The commodification of culture led to cultural changes because of tourism purposes.

\section{Role of Customary Institution}

Indigenous villages have been recognized and participated directly in the management of local tourism. This can be seen in the process of determining the operational costs of the attraction, recruitment majority are local indigenous villagers, and local tourism revenue management (Santosa, 2003). Indigenous villages have a significant role in managing the local economy, they are a self-regulated body. 1984 Bali provincial government started the establishment of Village Credit Institutions (LPD) throughout Pakraman villages by issuing Governor Decree No. 972 of 1984 on the establishment of Village Credit Institutions. The existence of regulated LPD Regional Regulation (Perda) the Bali Provincial Regulation No. 8 of 2002 on Credit Institutions village, which has been revised to Bali Provincial Regulation No. 3 of 2007. The LPD investment activity helped the growth and development of small industrial businesses and local households (Nyoman Y., 2010).

Besides the economic aspect, the investment activity of Pakraman has played a significant role in preserving Balinese culture, because the Hindu life, social order, and arts and culture or social and cultural life in Bali everything rests on Pakraman. According to I Gusti Ngurah Arya Wedakarna as a member of the House of Regional Representatives, the role of Bali traditional institutions in investment activity is vital, especially for licensing issues. In this case, the role of traditional institutions is decisive that filter out the impact of investment activity on Bali culture. When issuing an investment permission local government must coordinate with the local indigenous villages so that there is no clash between the government and the traditional institution. I Gusti Ngurah Arya Wedakarna added that this coordination with the customs agency is actually only limited to recommendations but it plays the most important stage in investment permission procedure.

\section{Institutional Analysis Services And Investment Licensing}

\section{Test Strategy}

In order to promote sustainable investment and quality service of investment activities, Bali provincial administration launched bureaucratization policy through the establishment of One Stop Services (OSS). The establishment of OSS leaned up the bureaucracy, integrate all permission processes, and shortening the service as well as the physical distance with the public (Prasojo et al, 2007). Foreign investor domination, especially investment in the tourism sector is a controversial issue in this context. Until now tourism investment in Bali is dominated by foreigners. About 80 percent of the total investment in the tourism sector which is the main engine of Bali economic development comes from foreign capitalists (Suantika, 2015).

\section{Institutional Advantage Test}

From the aspect of business and investment permission, OSS Office in Bali plays as a clearing house for the traffic information. Bali OSS is still improving where there has been a 6 OSS with high authority level (more than 20 types of investment permission) and 3 PTSP in the category of medium authority level (10-20 permits) so that its existence actually cut the bureaucracy (Jaweng, 2014).

PTSP Bali also has utilized SPIPISE (Electronic System of Information Services and Investment Licensing). The system is an electronic foundation for investment permission process so that investors can 
obtain a wide range of services and information about permission procedure. This SPIPISE services make investment procedure become simple, cheap, efficient, and predictable. The applicant can take care of their licensing with technological devices without the need for direct contact with service officers (Jaweng, 2014).

\section{Feasibility Test}

In creating a conducive business climate, Bali Provincial Investment Board held an annual forum of business gathering, which brought domestic investors, foreign investors and the local community leaders (Erviantono, 2012). Unfortunately, this activity is only done at the provincial level and has not spread in all districts/cities. Investment activities in some areas are not running optimally.

Integrity and capacity of government officials were always highlighted. Some cases related integrity arisen, such as popular cases that attract a lot of people attention is BPPT Badung that was considered deliberately complicate the process so that cost and length of time to get permission are not transparent. Officer capacity is also an important issue, for example, that is analyzed by Erviantono (2015) that Klungkung region is less attractive to investors because of the poor capacity of the existing personnel in the OSS.

\section{Difficult Link Test}

Vertical and horizontal coordination that are related to the provision of permission and non-permission affair in the province of Bali has got significant support from nationally integrated SPIPISE between BKPM (databases and systems) with various ministry/ government agencies. Although the level of institutional status is not directly correlated with the level of authority, level of institutional forms is a relatively very low form so in some areas in Bali effectiveness of the agency's performance was seriously affected. Problems were found mainly related to relations with the provincial government office leaders (SKPD) in coordinating the provision of recommendations, decisions on the results of field verification, the status of administrative levy obtained from the business of permission process (Jaweng, 2014).

\section{Redundant Hierarchy Test}

An institution must consider the aspect of specialization and coordination internally between the units (Galbraith and Kates, 2002). Establishment and implementation of OSS in Bali Investment Board are the leading agency with the involvement of the regional government units or offices in the province, especially related to investment such as; Department of Industry and Trade, Tourism, Plantation, and other central, provincial, and regional offices (SKPD). Division of work among sectors is relatively good because Bali is considered to be the ideal model for OSS for another province (Jaweng, 2014).

In practice PTSP under BPMP Bali had been already given authorities in managing the investment permission services, BPMP also has the authority to govern non-licensing services related to investment. Meanwhile, for operational licenses, government technical office issue some permission such as: Building Permit (IMB), Social Permit (HO), Licensed Environmental Impact Assessment (AMDAL) according to the jurisdiction of the respective SKPD in the area.

\section{The Accountability Test}

Institutional management of business and investment in Bali province is already quite clear regulated in the Governor regulation No. 82 of 2011 about details of Main Duties Investment Board Licensing Bali Province (BPMP). BPMP Bali has the task to carry out the preparation and implementation of regional policy in investment and business permission. Meanwhile, the authority has been submitted to the Integrated Licensing Services Office (KPPT) Bali province on July 28, 2008 based on Bali Provincial Regulation No. 2 of 2008.

However, there is still problems in its implementation, particularly the investment activity in the tourism sector. There is no certain division of supervision authority between various government agency. The local government finally publishes tourism accommodation moratorium that was issued by the Provincial Government of Bali in a Circular Letter (SE) Bali Governor No.570/ 1665/ BPM dated December 27, 2010 which states the temporary suspension of the construction of tourism accommodation and capital investment in accommodation services. The letter followed up by the City of Denpasar, Gianyar and Badung because these three regions experienced a saturated infrastructure capacity (Mastuty et al, 2015).

Weak supervision system could threaten the preservation of Balinese cultural identity 
UUD 1945

UUDS 1950

UU Nomor 64 Tahun 1958, UU Nomor 23 Tahun 2014, UU Nomor 28 Tahun 2009 , UU Nomor 10 Tahun 2004, UU Nomor 33 Tahun 2004, UU Nomor 25 Tahun 2007, UU Nomor 40 Tahun 2007, UU No. 26 Tahun 2007 , UU No. 5 Tahun 1960
Revisited:

1. Legal Base of Provincial Formation

2. Nominee Agreement

3. Permission Service Revenue Administration

4. Revenue Sharing
24 Tahun 2006, Permendagri No. 3 Tahun 1997
Pergub Nomor 63 Tahun 2014, Perda Nomor

16 Tahun 2009 , Pergub Nomor 8 Tahun 2007,

Perda Nomor 2 Tahun 2012 , Perda Nomor 3

Tahun 2003 , Pergub Bali No36 Tahun 2009,

Pergub No 37 Tahun 2009
Revisited:

Legal Base of PTSP

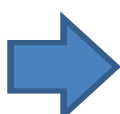

Figure 1

Empirical Study of Juridical and Socio Legal Institutional Investment Permit in Bali

based on the concept of Tri Hita Karana that is supported by the existence of traditional village (Santosa, 2003). The existence of indigenous villages is very important in order to reduce the negative impact of investment activity in Bali (Widyatmaja, 2011). Bali government accommodate the spirit of the investment in the island by issuing the Decree No 2138/02-C/HK/2012 on licenses and rights to utilize and develop the PT Benoa Bay. Wahana Tirta Bali International (PT. TWBI) covering an area of 838 ha. However, the Governor Decree has huge public rejection from various social components, including some indigenous communities. The reason for rejection is, among others, related to do with religion, socio-cultural, political, and economic issue (Suantika, 2015).

\section{Conclusions}

Based on an analysis conducted in juridical and empirical socio legal, Bali institutional business and investment problem can be concluded in Figure 1 . Figure 1 shows that to optimize the institutional efforts and investments in creating economic equality in the province of Bali, the government needs to revisit the regulation related to the establishment of the province of Bali namely Law No. 64 of 1958 which refers to the Provisional Constitution of 1950 which is not aligned with the spirit of decentralization / autonomy and hamper management optimization potential of the region. In creating economic justice, need to be revisited Law 33 of 2004 on the budget 
balance between the center and regions, more specifically associated with revenue-sharing that is used for the preservation of Balinese culture. In order to reduce economic disparity, it is necessary to issue local regulations related to incentives and ease of investment, especially in areas that are still lagged behind. Furthermore, there is a legal vacum in Law No. 25 of 2007 and Law. No. 40 of 2007 related to the nominee agreement where this practice is rampant in investment activity and business climate certainty in the future that potentially cause problems for both the investor and the surrounding community.

Disharmony in permit services revenue authority based on Act No. 23 of 2014 and Law No. 28 of 2009 created confusion in businesses community. Disharmony also occurs in the regulation of the formation of one-stop services office (PTSP) because of policy coordination and synchronization problems. Related to environmental sustainability, the areas in Bali still do not have legal formal support. The phenomenon of cultural commodification shows that the regulation of tourism in Act. No. 2 of 2012 needed to be further translated into more detailed rules in order to preserve the culture in the area.

The preservation of nature and culture is largely determined by the presence of indigenous villages. Indigenous villages is the typical central point of Bali cultural development and preservation. There is a wrong view of investors that considered indigenous villages hamper economic and investment activity. The indigenous villages were perceived to extend the investment permission bureaucracy. Indigenous village empowerment has been got large attention after the reform era, but its planning and supervision of investment activities conducted by indigenous villages have not been in an optimal pace so can face many problems that potentially erode Balinese cultural identity because of investment activity.

Associated with the investment permission service institutions, institutional permits in Bali has been run through the bureaucratization process. The existence KPPT brings the benefits of the clearing house function for the traffic information service and the investors through its performance as one stop services office. However, an institutional lowest form of office has a serious effect to the effectiveness of the agency's performance because the lower status of the office made an awkward relationship with the sectoral SKPD leaders. In order to improve the business and investment climate in Bali and create economic equality in Bali it needs an effort to improve existing business and investment institutions and also give special attention to preservation of Bali social and cultural identity.

\section{References}

Bank Indonesia. (2015) Kajian Ekonomi dan Keuangan Regional (KERK) Provinsi Bali Triwulan I 2015

Bromley, C (1989). Economic Interests and Institutions. New York: Harper and Row.

Darmadi, I Gusti Ngurah Eka. (2011) "Representasi Budaya Masyarakat Lokal Dan Politik Identitas Desa Adat Kuta dalam Poskolonialitas Kawasan Industri Pariwisata." Tesis UNUD. Bali (tidak diterbitkan)

Dewantara, Made Handijay. (2015) Bali Punya Siapa?. Inspirator Academy

Djogo, T, Sunaryo, D. Suharjito, dan M. Sirait. (2003). Kelembagaan dan Kebijakan dalam Pengembangan Agroforestri. World Agroforestry Centre (ICRAF). Bogor

Galbraith, J and K, Amy, (2002). Designing Effective Organizations. San Francisco: California: Jossey-Bass Inc.

Galbraith, J (2005). Designing Organizations: An Executive Briefing on Strategy, Structure, and Process, San Francisco: California: Jossey-Bass Inc.,

Goold, M and A, Campbell (2002). "Do You Have a Well-Designed Organization?," Harvard Business Review.

Gorda, I Gusti Ngurah. (1999). Manajeman dan kepemimpinan desa Adat di Propinsi Bali Dalam Perspektif Era GloBalisasi, STIE, Singaraja dan PT. Widya Kriya Gematama, Denpasar.

Gunawan, K (2011) Peran Falsafah Tri Hita Karana Bagi Pertumbuhan dan Kinerja Lembaga Perkreditan Desa (LPD) di Bali, Analisa Manajemen, Volume 5, Fakultas Ekonomi Universitas Panji Sakti, Singaraja, Hal.29-32.

Harmini dan Solihin, (2013). Peranan desa adat (pakraman) dan sekaa taruna dalam menunjang pariwisata di Bali. Jurnal Sosial dan Humaniora, vol. 3, no. 3.

Harsono, B (2003), Hukum Agraria, Sejarah Pembentukan Undang-Undang Pokok Agraria Isi dan Pelaksanaannya, Jilid I Hukum Tanah Nasional, Edisi Revisi, Djambatan, Jakarta, hal. 265.

Jaweng, R.E (2014). Reformasi Birokrasi Perizinan Usaha di Daerah. Jurnal Ilmu 
Pemerintahan Edisi 45 Tahun 2014

Mahmud Marzuki, P (2002). Jurisprudence as sui Generis Dicipline, Yudika, Vol. 17 No. 4, Juli 2002, hlm. 312-314.

North, D. C (1990). Institutions, Institutional change and economic performance. Cambridge University Press

Pemerintah Provinsi Bali. (2014)Rencana Umum Penanaman Modal Provinsi Bali 2014-2025

Pemerintah Provinsi Bali.(2016) Rencana Kerja Pembangunan Daerah Bali Tahun 2016

Prasojo, E (2007), "Deregulasi dan Debirokratisasi Perizinan di Indonesia". Departemen Ilmu Administrasi Fisip UI,

Purnamasari, Ni Putu Diah, (2014). Pemerintah Bali Dalam Mengembangkan Pariwisata Pasca Bom Bali I Dan II. eJournal Ilmu Hubungan Internasional, 2014, 2 (2): 351-362

Soni Qodri, M (1997) "Bali dan Sengketa Agraria," dalam Reformasi Agraria, Perubahan Politik, Sengketa, dan Agenda Pembaruan Agraria di Indonesia, Dianto, Erpan Faryadi, dan Bonnie Setiawan (Eds), Lembaga Penerbit Fakultas Ekonomi Universitas Indonesia. Hal. 275

Suantina, M (2002) Desa Pakraman: Sejarah, Eksistensi dan Strategi Pemberdayaan. Yayasan Tri Hita karana,
Suantika, Wayan. (2015) Resistensi Masyarakat Lokal terhadap Kapitalisme Global: Studi Kasus Reklamasi Teluk Benoa Bali Tahun 2012-201. Jurnal Hubungan Internasional. Tahun VIII, No.1, Januari - Juni 2015

Sondakh J. (2015)Model Pengaturan Investasi Vol.II/No.2/Januari-Maret /2014 Edisi Khusus

Suwitra, I Made Suwitra. (2013) Kepastian Hukum Penguasaan Hak Atas Tanah Untuk Investasi. Makalah disampaikan dalam seminar Refleksi Akhir tahun 2013 Penegakan Hukum kerja sama Prodi Magister Ilmu Hukum Pascasarjana Unwar dengan Nusadua Post.

Triana Mastuty, Piers Andreas Noak, Ni Wayan Supriliyani. (2015) Implementasi Kebijakan Pemerintah Provinsi Bali Dalam Moratorium Pembangunan Infrastruktur Akomodasi Pariwisata Hotel Di Kabupaten Badung.Online Jurnal System Universitas Udayana. Vol 1, No 2.

Widyatmaja, I Gusti Ngurah, (2011). Pariwisata budaya Bali di tengah arus Globalisasi. Jurnal Ilmiah Pariwisata, Trisakti Vol. 16 No. 2, Juli 2011

Widana, I Gusti Ketut, (2002) Mengenal Budaya Hindu di Bali, PT. BP Denpasar, Denpasar, Hal. 24. 